\title{
Pengaruh Garansi, Promosi dan Kualitas Produk Terhadap Keputusan Pembelian Produk Moorlife di Kota Jambi
}

\author{
Agesha Marsyaf \\ Program studi Manajemen Fakultas Ekonomi dan Bisnis Universitas Muhammadiyah Jambi \\ Correspondence email: agesha.marsyaf.am@gmail.com
}

\begin{abstract}
Most Indonesians bringing food or drink has become a habit. Bringing provisions is currently positive for the development of household appliance manufacturers made of plastic, this is because its practical use, not easily broken, its attractive design and color make the reason why plastic products are loved by the community, one of which is Moorlife products from year to year experiencing a significant increase in sales. This research aims to find out partially and simultaneously the influence of promotion, warranty, and product quality on moorlife product purchase decisions in Jambi City. The method used is quantitative method. The data used is primary data obtained from in-person interviews and using questionnaires. The results showed that the Promotion, Warranty and Quality of Products had a positive and significant effect on the decision of consumers to buy Moorlife Products in jambi City. And overall Promotion, Warranty and Product Quality contributed 46.4\% to Moorlife Products in Jambi City.
\end{abstract}

Keywords: Promotion, Warranty, Product Quality, Purchase Decision

\section{Pendahuluan}

Saat ini di Indonesia kebanyakan orang membawa bekal makanan atau minuman telah menjadi kebiasaan. Manfaat membawa bekal tidak hanya untuk menghemat uang, membawa bekal juga salah satu cara yang dapat digunakan untuk membangun pola hidup yang sehat dan ramah lingkungan. Apalagi setelah Pemerintah menerbitkan protokol normal baru (New Normal) bagi perkantoran dan industri dalam menghadapi pandemi virus corona atau Covid-19 yang diatur dalam Kemenkes No. HK.01.07/Menkes/328/2020 tentang Panduan Pencegahan dan Pengendalian Covid-19 di Tempat Kerja Perkantoran dan Industri dalam Mendukung Keberlangsungan Usaha pada Situasi Pandemi. Pada point ke 17 menjelaskan bahwa Hindari penggunaan alat pribadi secara bersama seperti alat shalat, alat makan, dan lain lain. Demi mencegah penularan salah satunya dengan membawa wadah bekal dan botol minum sendiri.

Membawa bekal saat ini berdampak positif untuk perkembangan produsen alat-alat rumah tangga yang terbuat dari plastik. Disamping penggunaanya yang praktis, tidak mudah pecah, desain dan warnanya yang menarik menjadikan alasan mengapa produk plastik digandrungi oleh masyarakat. Banyak kita temukan produk rumah tangga terbuat dari plastik yang memiliki kualitas produk yang baik, misalnya Moorlife. Selain Moorlife produk pesaing yang memiliki kualitas sama baiknya seperti Tupperware, Tulipware, Lock n Lock dan Rubbermaid yang sudah lebih dahulu memperkenalkan produk-produk terbaik mereka. Walaupun Moorlife sendiri masih baru, tetapi kini telah dikenal banyak orang karena bahannya yang lebih tebal dari produk sejenis,warna-warna lebih menarik serta asli buatan Indonesia. Untuk mengatasi persaingan maka setiap perusahaan perlu menciptakan produk yang memiliki keunggulan kompetitif dengan cara memperhatikan faktor-faktor yang dapat mebantu untuk mempengaruhi keputusan pembelian. Yuli (2017) keputusan pembelian adalah suatu proses pengambilan keputusan akan pembelian yang mencakup apa yang akan dibeli dan tidak melakukan pembelian.Keputusan pembelian adalah tindakan dari konsumen untuk mau membeli atau tidak terhadap produk. Berbagai faktor yang mempengaruhi konsumen dalam melakukan pembelian suatu produk atau jasa, biasanya konsumen selalu mempertimbangkan kualitas, harga, dan produk yang sudah dikenal oleh masyarakat (Wahyono, 2012). Setiap akan melakukan keputusan pembelian, konsumen akan melakukan evaluasi terhadap dirinya. Pada dasarnya keputusan untuk membeli suatu produk dipengaruhi banyak faktor antara lain kualitas suatu produk, merek, selera, harga danpromosi yang ditawarkan oleh perusahaan (Sulistyaningtyas, dkk, 2017).

Untuk menarik minat konsumen membeli produk yang ditawarkan maka dibutuhkan adanya promosi yang efektif, harga yang kompetitif dibandingkan harga yang ditawarkan pesaing, kualitas produk yang bermutu dan juga layanan purna jual yang mampu memberikan kepuasan kepada pelanggan. Menariknya promosi yang ditawarkan akan mempengaruhi minat konsumen untuk mencoba mengkonsumsi produk tersebut. Promosi adalah aktivitas pemasaran yang berusaha menyebarkan informasi, mempengaruhi atau membujuk, dan mengingatkan pasar sasaran atas perusahaan dan produknya agar bersedia menerima, membeli dan loyal pada produk yang ditawarkan perusahaan yang bersangkutan (Fajar, 2015).

Melakukan Promosi menggunakan Iklan atau melakukan pameran juga sangat berguna untuk strategi pemasaran. Begitu juga produk Moorlife selain aktif di offline maupun online di Social Media, Moorlife juga sering 
mengadakan event-event yang bermanfaat untuk kepentingan lingkungan dan masyarakat berupa CMN Go Healthy, Biochef Cooking Show, CMN Donor Darah dan masih banyak lagi. Selain itu Moorlife memberikan kesempatan jalan-jalan gratis ke dalam dan luar negeri untuk seluruh konsumen yang mencapai target pengejaran Challange serta Moorlife juga memberikan reward untuk setiap minimal pembelanjaan yang ditentukan mulai dari gift per satu juta, e-reward senilai 140.000 , activity produk moorlife, dan bonus uang dengan cara di transfer ke rekening. Penelitian terdahulu yang telah dilakukan ternyata promosi berpengaruh signifikan secara parsial terhadap Keputusan Pembelian Konsumen PT Astra Daihatsu Tbk. Cab. Malalayang (Andrew, 2016). Kemudian dalam penelitan yang dilakukan Jilly (2003) menunjukkan adanya pengaruh yang positif dan signifikan variabel promosi terhadap keputusan pembelian rokok Surya ProMild. Hasil ini menunjukkan bahwa penilaian yang baik mengenai promosi yang sesuai dengan tingkat keinginan konsumen akan mendorong konsumen untuk melakukan pembelian produk tersebut.

Selain promosi melalui acara atau kegiatan yang bermanfaat produk Moorlife juga memberikan Moor Lifetime Guatantee (garansi seumur hidup) terhadap produk moorlife dengan ketentuan dan syarat pemakaian normal. Kebanyakan garansi hanya ada pada produk elektronik tapi pada saat sekarang produk dengan suatu merek Moorlife yang berupa peralatan rumah tangga berbahan plastik juga mampu memberikan garansi. Garansi adalah surat keterangan dari suatu produk bahwa pihak produsen menjamin produk tersebut bebas dari kesalahan pekerja dan kegagalan bahan dalam jangka waktu tertentu (Wikipedia, 2020). Garansi ini sangat berharga sebab dengan adanya garansi, selain menjamin kualitas produk tersebut juga mepengaruhi harga jual dan minat pembelian suatu produk. Dengan adanya garansi, nilai jual suatu produk akan bertambah dan keberadaan garansi tersebut dapat meningkatkan minat konsumen untuk membelinya. Penelitian terdahulu yang telah dilakukan menyatakan bahwa garansi produk berpengaruh terhadap keputusan pembelian smartphone dan hipotesis pertama dinyatakan dapat diterima (Gunawan, 2017). Namun pada kenyataannya garansi tetap dibatasi dengan jangka waktu tertentu sehingga konsumen tidak dapat menerima garansi setiap waktu. Istimewanya pada produk Moorlife, perusahaan memberikan garansi produk seumur hidup sehingga secara tidak langsung akan meningkatkan kepercayaan konsumen terhadap produk Moorlife.

Tabel 1

Data Penjualan Moorlife di Jambi

\begin{tabular}{lrrr}
\hline \multirow{2}{*}{ Bulan } & \multicolumn{1}{c}{ Tahun } \\
\cline { 2 - 4 } Januari & 2017 & 2018 & 2019 \\
Februari & Rp221.615.000 & Rp162.662.014 \\
Maret & Rp323.600.000 & Rp352.290.195 \\
April & Rp388.027.500 & Rp293.334.356 & Rp470.695.190 \\
Mei & Rp305.355.000 & Rp767.439.761 & Rp497.087.560 \\
Juni & Rp265.438.000 & Rp157.550.000 & Rp431.396.000 \\
Juli & Rp319.644.000 & Rp63.451.131 & Rp492.596.000 \\
Agustus & Rp268.505.000 & Rp144.171.046 & Rp470.901.030 \\
September & Rp272.137.000 & Rp370.345.000 & Rp498.980.000 \\
Oktober & Rp375.825.000 & Rp79.651.200 & Rp172.396.000 \\
November & Rp80.264.570 & Rp150.812.000 & Rp75.354.030 \\
Desember & Rp302.472.000 & Rp193.592.180 & Rp84.956.000 \\
Total & Rp170.765.000 & Rp692.961.000 & Rp3.884.399.019 \\
\hline
\end{tabular}

Sumber: data olahan

Mengenai hal ini secara tidak langsung juga Moorlife percaya diri menjamin bagaimana kualitas yang melekat pada produk. Kualitas produk adalah kemampuan suatu produk untuk melaksanakan fungsinya, meliputi kehandalan, daya tahan, ketepatan, kemudahan operasi, dan perbaikan produk, serta atribut bernilai lainnya. Setiap perusahaan yang menginginkan dapat memenuhi kebutuhan dan keinginan pelanggan, maka akan berusaha membuat produk yang berkualitas, yang ditampilkan baik melalui ciri-ciri luar (design) produk maupun inti (core) produk itu sendiri. Tabel 1 menunjukkan bahwa penjualan Moorlife di Jambi mencapai omset Milyaran rupiah pada setiap tahunnya. Tabel 1 menjelaskan bahwa beberapa bulan tertentu mengalami peningkatan omset yang tinggi karena para konsumen mengikuti Challange yang diadakan oleh CMN yaitu Jalan-jalan gratis Luar dan Dalam Negeri yang diadakan setiap tahunnya. Sehingga sampai saat ini Moorlife tetap diminati para konsumen karena kualitasnya yang sangat baik. Beberapa konsumen Moorlife yang peneliti observasi mengatakan bahwa Moorlife lebih tebal dan warna nya cerah ada juga yang mengatakan Moorlife produk Indonesia, bahan nya juga lebih tebal \& warnanya lebih menarik kemudian Asli produk dalam negeri, lebih bagus kualitasnya. 


\section{Hasil}

Tabel 2

Karakteristik Konsumen Berdasarkan Jenis Kelamin

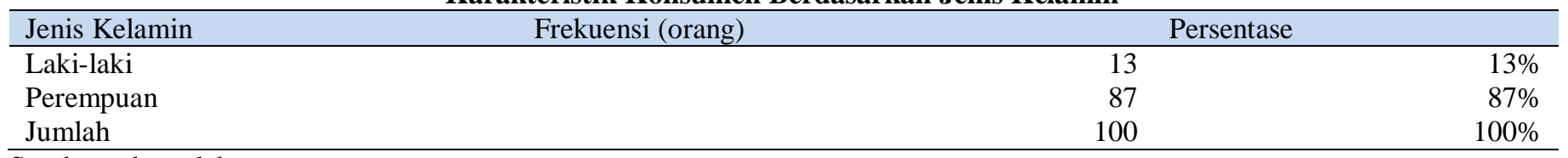

Sumber : data olahan

Tabel 2 diketahui bahwa responden yang berjenis kelamin perempuan lebih tinggi jika dibandingkan dengan laki-laki, yakni perempuan dengan 87 responden atau 87\%, dan laki-laki 13 responden atau 13\% dari total keseluruhan responden. Tabel 3 diketahui bahwa responden yang berusia $18-22$ Tahun berjumlah 6 responden atau $6 \%, 23-27$ Tahun berjumlah 32 responden atau 32\%, 28 - 32 Tahun berjumlah 22 responden atau 22\%, 33 - 37 Tahun berjumlah 28 responden atau 28\%, 38 - 42 Tahun berjumlah 5 responden atau 5\%, dan $>42$ Tahun berjumlah 7 responden atau $7 \%$. Hasil data tersebu bahwa konsumen yang pernah membeli moorlife terbanyak adalah konsumen berusia $23-27$ Tahun dan 33 - 37 Tahun. Berdasarkan Tabel 4, wilayah kecamatan dengan responden tertinggi berada di Kecamatan Paal Merah sebanyak 17 responden atau 17\% dan Kecamatan Jambi Selatan sebanyak 15 responden atau 15\%, sedangkan wilayah terendah berada di 2 Kecamatan yaitu Kecamatan Alam Barajo dan Kecamatan Pelayangan. Tabel 5 dengan jumlah 100 responden, peneliti membagi kuantitas pembelian produk menjadi 3 tingkat, tanggapan terbanyak yang di dapat menunjukkan 38\% responden yang membeli 2 - 5 kali produk Moorlife, kemudian $30 \%$ responden yang membeli 6 - 9 kali, dan 30\% responden yang membeli produk Moorlife sebanyak > 10 kali.

Tabel 3

Karakteristik Konsumen Berdasarkan Umur

\begin{tabular}{|l|r|r|}
\hline \multicolumn{1}{|c|}{ Umur } & Frekuensi (orang) & \multicolumn{1}{|c|}{ Persentase } \\
\hline $18-22$ Tahun & 6 & $6 \%$ \\
\hline $23-27$ Tahun & 32 & $32 \%$ \\
\hline $28-32$ Tahun & 22 & $22 \%$ \\
\hline $33-37$ Tahun & 28 & $28 \%$ \\
\hline $38-42$ Tahun & 5 & $5 \%$ \\
\hline$>42$ Tahun & 7 & $7 \%$ \\
\hline Jumlah & 100 & $100 \%$ \\
\hline
\end{tabular}

Sumber : data olahan

Tabel 4

Karakteristik Konsumen Berdasarkan Klasifikasi Wilayah

\begin{tabular}{|l|r|r|}
\hline \multicolumn{1}{|c|}{ Kecamatan } & \multicolumn{1}{c|}{ Frekuensi (orang) } & Persentase \\
\hline kec. Telanai Pura & 13 & $13 \%$ \\
\hline kec. Kota Baru & 12 & $12 \%$ \\
\hline kec. Jelutung & 8 & $8 \%$ \\
\hline kec. Pasar jambi & 5 & $5 \%$ \\
\hline kec. Jambi Timur & 14 & $14 \%$ \\
\hline kec. Jambi Selatan & 15 & $15 \%$ \\
\hline kec. Danau Sipin & 5 & $5 \%$ \\
\hline kec. Paal Merah & 17 & $17 \%$ \\
\hline kec. Alam Barajo & 2 & $2 \%$ \\
\hline kec. Pelayangan & 4 & $4 \%$ \\
\hline kec. Danau teluk & 5 & $5 \%$ \\
\hline Jumlah & 100 & $100 \%$ \\
\hline
\end{tabular}

Sumber : data olahan

Tabel 5

Karakteristik Konsumen Berdasarkan Kuantitas Pembelian Produk Moorlife

\begin{tabular}{|l|r|r|}
\hline Kuantitas Pem belian Produk Moorlife & Frekuensi (orang) & Persentase \\
\hline $2-5 \mathrm{Kali}$ & 38 & $38 \%$ \\
\hline $6-9 \mathrm{Kali}$ & 30 & $30 \%$ \\
\hline$>10 \mathrm{Kali}$ & 32 & $32 \%$ \\
\hline Jumlah & 100 & $100 \%$ \\
\hline
\end{tabular}

Sumber : data olahan 
Tabel 6

Coefficients $^{\mathrm{a}}$

\begin{tabular}{|c|c|c|c|c|c|c|}
\hline \multirow{2}{*}{\multicolumn{2}{|c|}{ Model }} & \multicolumn{2}{|c|}{ Unstandardized Coefficients } & \multirow{2}{*}{\begin{tabular}{c|} 
Standardized Coefficients \\
Beta \\
\end{tabular}} & \multirow[b]{2}{*}{$\mathrm{t}$} & \multirow[b]{2}{*}{ Sig. } \\
\hline & & B & Std. Error & & & \\
\hline \multirow[t]{4}{*}{1} & (Constant) & 1.143 & 3.089 & & .370 & .712 \\
\hline & Promosi (X1) & .328 & .050 & .529 & 6.580 & .000 \\
\hline & Garansi (X2) & .328 & .109 & .243 & 3.018 & .003 \\
\hline & Kualitas Produk (X3) & .185 & .093 & .150 & 1.998 & .049 \\
\hline
\end{tabular}

Sumber : data olahan

\section{Hipotesis 1}

Pengaruh variabel promosi (X1) secara parsial/individu terhadap keputusan pembelian konsumen produk Moorlife (Y). Pada tabel 6, maka dapat dilihat bahwa t hitung untuk promosi (X1) sebesar 6,580 hal ini berarti $\mathrm{t}$ tabel $1,9839<\mathrm{t}$ hitung 6,580 kemudian hasil signifikasi sebesar 0,000 yaitu < 0,05 maka H0 ditolak dan H1 diterima. Maka kesimpulannya ada pengaruh positif dan signifikan promosi (X1) terhadap keputusan pembelian konsumen produk Moorlife (Y).

Hipotesis 2

Pengaruh variabel garansi (X2) secara parsial/individu terhadap keputusan pembelian konsumen produk Moorlife (Y). Pada tabel 6, maka dapat dilihat bahwa t hitung untuk garansi (X2) sebesar 3,108 hal ini berarti tabel 1,9839 < $\mathrm{t}$ hitung 3,108 kemudian hasil signifikasi sebesar 0,003 yaitu < 0,05 maka H0 ditolak dan H1 diterima. Maka kesimpulannya ada pengaruh positif dan signifikan garansi (X2) terhadap keputusan pembelian konsumen produk Moorlife (Y).

Hipotesis 3

Pengaruh variabel kualitas produk (X3) secara parsial/individu terhadap keputusan pembelian konsumen produk Moorlife (Y).

Tabel 6 dapat dilihat bahwa t hitung untuk kualitas produk (X3) sebesar 1,998, hal ini berarti $t$ tabel $1,9839<\mathrm{t}$ hitung 1,998 kemudian hasil signifikasi sebesar 0,049 yaitu < 0,05 maka H0 ditolak dan H1 diterima. Maka kesimpulannya ada pengaruh positif dan signifikan kualitas produk (X3) terhadap keputusan pembelian konsumen produk Moorlife (Y). Hasil analisis regresi linier berganda, diperoleh persamaan regresi yaitu:

$\mathrm{Y}=1,143+0,328 \mathrm{X} 1+0,328 \mathrm{X} 2+0,185 \mathrm{X} 3$

Interpretasi dari persamaan model regresi di atas, sebagai berikut :

1. Bilangan konstanta mempunyai nilai sebesar 1,143 (positif) bahwa jika mengabaikan promosi (X1), Garansi (X2) dan kualitas produk (X3) maka skor pengambilan keputusan konsumen dalam membeli produk Moorlife (Y) adalah 1,143. Artinya masih tetap ada pengambilan keputusan konsumen dalam membeli produk Moorlife walaupun nilai X1, X2 dan X3 terhadap Y bernilai nol (0).

2. Koefisien regresi variabel Promosi (X1) sebesar 0,328 artinya jika variabel promosi mengalami kenaikan satu kesatuan maka keputusan konsumen melakukan pembelian terhadap produk Moorlife (Y) akan meningkat sebesar 0,328 dengan asumsi variabel independen lainnya bernilai tetap.

3. Koefisien regresi variabel Garansi (X2) sebesar 0,328 artinya jika variabel garansi mengalami kenaikan satu kesatuan maka keputusan konsumen melakukan pembelian terhadap produk Moorlife (Y) akan meningkat sebesar 0,328 dengan asumsi variabel independen lainnya bernilai tetap.

4. Koefisien regresi variabel Kualitas Produk (X3) sebesar 0,185 artinya jika kualitas produk mengalami kenaikan satu kesatuan, maka keputusan konsumen melakukan pembelian terhadap produk Moorlife (Y) akan mengalami penurunan sebesar 0,185 dengan asumsi variabel independen bernilai tetap.

Tabel 7

Uji Simultan (Uji F)

\begin{tabular}{|l|l|r|r|r|r|r|}
\hline \multicolumn{2}{|c|}{ Model } & \multicolumn{1}{c|}{ Sum of Squares } & Df & Mean Square & F & Sig. \\
\hline \multirow{3}{*}{1} & Regression & 243.355 & 3 & 81.118 & 27.654 & $.000^{\mathrm{a}}$ \\
\cline { 2 - 7 } & Residual & 281.605 & 96 & 2.933 & & \\
\cline { 2 - 8 } & Total & 524.960 & 99 & & & \\
\hline
\end{tabular}

Sumber : data olahan 
Tabel 7 dilihat bahwa nilai f hitung sebesar 27,654. Hal ini berarti f hitung 27,654 > f tabel 2,70, maka H0 ditolak dan H1 diterima. Maka kesimpulannya ada pengaruh positif dan signifikan antara promosi (X1), garansi (X2) dan kualitas produk (X3 ) secara simultan/bersama-sama terhadap keputusan pembelian konsumenproduk Moorlife (Y).

Tabel 8

Koofisien Determinasi

\begin{tabular}{|c|c|r|r|r|}
\hline Model & R & R Square & Adjusted R Square & \multicolumn{1}{c|}{ Std. E rror of the Estimate } \\
\hline 1 & $.681^{\mathrm{a}}$ & .464 & .447 & 1.713 \\
\hline
\end{tabular}

Sumber : data olahan

Tabel 8 didapat hasil analisis determinasi diperoleh koefisien determinasi yaitu nilai $\mathrm{R}^{2}(R$ Square) sebesar 0,464 atau $46,4 \%$. Kesimpulannya yaitu persentase pengaruh variabel bebas yaitu promosi (X1), garansi (X2) dan kualitas produk (X3) terhadap keputusan pembelian konsumen terhadap produk Moorlife sebesar 46,4\%, sedangkan $53,6 \%$ dipengaruhi variabel-variabel lain diluar model penelitian.

\section{Pengaruh Variabel Promosi Terhadap Keputusan Pembelian Produk Moorlife di Kota Jambi.}

Hasil analisis statistik variabel promosi (X1) secara parsial/individu terhadap keputusan pembelian konsumen terhadap produk Moorlife (Y) menunjukkan bahwa t hitung untuk variabel promosi (X1)sebesar 6,580 hal ini berarti t tabel 1,9839 < t hitung 6,580 kemudian hasil signifikasi sebesar 0,000 yaitu < 0,05 maka tidak ada pengaruh positif dan signifikan antara promosi terhadap keputusan pembelian produk Moorlife di Kota Jambi sebagai H0 ditolak dan Ada pengaruh positif dan signifikan antara promosi terhadap keputusan pembelian produk Moorlife di Kota Jambi sebagai H1 diterima. Maka kesimpulannya ada pengaruh positif dan signifikan promosi (X1 ) terhadap keputusan pembelian konsumen terhadap produk Moorlife (Y). Hasil ini memberikan bukti empiris bahwa promosi yang dilakukan oleh Moorlife sangat menarik bagi konsumen untuk membeli produk Moorlife karena Moorlife selalu memperbaharui promo-promonya setiap bulan melalui Katalog Promo Bulanannya dan selalu mengadakan Flash Promo atau Big Promo pada waktu tertentu.

\section{Pengaruh variabel Garansi Terhadap Keputusan Pembelian Produk Moorlife di Kota Jambi.}

Hasil analisis statistik variabel garansi (X2) secara parsial/individu terhadap keputusan pembelian konsumen terhadap produk Moorlife (Y) menunjukkan bahwa t hitung untuk variabel garansi (X2) sebesar 3,108 hal ini berarti t tabel 1,9839 < t hitung 3,108 kemudian hasil signifikasi sebesar 0,003 yaitu $<0,05$ maka tidak ada pengaruh positif dan signifikan antara garansi terhadap keputusan pembelian produk Moorlife di Kota Jambi sebagai H0 ditolak dan Ada pengaruh positif dan signifikan antara garansi terhadap keputusan pembelian produk Moorlife di Kota Jambi sebagai H1 diterima. Maka kesimpulannya ada pengaruh positif dan signifikan garansi (X2) terhadap keputusan pembelian konsumen terhadap produk Moorlife (Y). Hasil ini memberikan bukti empiris bahwa dengan adanya garansi produk konsumen dapat merasa tenang mengenai jaminan kualitas dari Moorlife, apalagi garansi yang diberikan tidak ada batasan waktu sehingga konsumen dapat menukarka produk yang mengalami kerusakan tanpa harus mengeluarkan biaya lain.

\section{Pengaruh variabel Kualitas Produk Terhadap Keputusan Pembelian Produk Moorlife di Kota Jambi.}

Hasil analisis statistik variabel kualitas produk (X3) secara parsial/individu terhadap keputusan pembelian konsumen terhadap produk Moorlife (Y) menunjukkan bahwa t hitung untuk variabel kualitas produk (X3) sebesar 1,998 hal ini berarti $t$ tabel $1,9839<\mathrm{t}$ hitung 1,998 kemudian hasil signifikasi sebesar 0,049 yaitu $<0,05$ maka tidak ada pengaruh positif dan signifikan antara kualitas produkterhadap keputusan pembelian produk Moorlife di Kota Jambi sebagai H0 ditolak dan Ada pengaruh positif dan signifikan antara kualitas produk terhadap keputusan pembelian produk Moorlife di Kota Jambi sebagai H1 diterima. Maka kesimpulannya ada pengaruh positif dan signifikan kualitas produk (X3) terhadap keputusan pembelian konsumen terhadap produk Moorlife (Y). Hasil ini memberikan bukti yang empiris bahwa kualitas produk yang diberikan Moorlife sangat baik karena Moorlife merupakan produk plastik kualitas premium dan BPA Free sehingga aman untuk makanan dan minuman yang kita konsumsi kemudian produk Moorlife ini merupakan produk asli Indonesia.

Pengaruh variabel promosi, garansi, dan kualitas produk terhadap keputusan pembelian produk Moorlife di Kota Jambi

Tabel 7 dapat dilihat nilai F hitung sebesar sebesar 27,654. Hal ini berarti f hitung 27,654 > f tabel 2,70, maka H0 ditolak dan H1diterima. Maka kesimpulannya ada pengaruh positif dan signifikan antara promosi (X1), garansi 
(X2) dan kualitas produk (X3) secara simultan/bersama-sama terhadap keputusan pembelian konsumenproduk Moorlife (Y). Tabel 8 didapat hasil analisis determinasi diperoleh koefisien determinasi yaitu nilai $\mathrm{R}^{2}$ ( $\mathrm{R}$ square) sebesar 0,464 atau 46,4\%. Kesimpulannya yaitu persentase pengaruh variabel bebas yaitu promosi (X1), garansi (X2) dan kualitas produk (X3) terhadap keputusan pembelian konsumen terhadap produk Moorlife sebesar 46,4\%, sedangkan 53,6\% dipengaruhi variabel-variabel lain diluar model penelitian. Hasil uji $\mathrm{F}$ (simultan) menunjukkan bahwa promosi (X1), garansi (X2), dan kualitas produk (X3) bersama-sama mempengaruhi keputusan pembelian (Y) sebesar 46,4\% yang berarti antara satu dengan yang laiin variabel-variabel independen ini saling berhubungan untuk mempengaruhi keputusan pembelian. Uji $\mathrm{F}$ ini dilakukan untuk melihat kelayakan model penelitian, jika hasil uji $\mathrm{F}$ tidak signifikan maka tidak disarankan untuk melakukan uji t (parsial).

\section{Simpulan}

Hasil analisis diperoleh bahwa variabel promosi (X1) memiliki koefisien regresi sebesar 0,328 (bertanda positif ) terhadap keputusan pembelian konsumen produk Moorlife (Y) dan nilai t hitung untuk promosi (X1) sebesar 6,580 hal ini berarti t tabel 1,9839 < t hitung 6,580 kemudian hasil signifikasi sebesar 0,000 yaitu < 0,05 maka H0 ditolak dan H1 diterima. Maka kesimpulannya ada pengaruh positif dan signifikan promosi (X1) terhadap keputusan pembelian konsumen produk Moorlife (Y). Hasil analisis diperoleh bahwa variabel garansi (X2) memiliki koefisien regresi sebesar 0,328 (bertanda positif) terhadap keputusan pembelian konsumen produk Moorlife (Y). dan nilai $\mathrm{t}$ hitung untuk garansi (X2) sebesar 3,108 hal ini berarti t tabel 1,9839< $\mathrm{t}$ hitung 3,108 kemudian hasil signifikasi sebesar 0,003 yaitu < 0,05 maka H0 ditolak dan H1 diterima. Maka kesimpulannya ada pengaruh positif dan signifikan garansi (X2) terhadap keputusan pembelian konsumen produk Moorlife (Y). Hasil analisis diperoleh bahwa kualitas produk (X3) memiliki koefisien refresi sebesar 0,185 terhadap keputusan pembelian konsumen produk Moorlife (Y) dan t hitung untuk kualitas produk (X3) sebesar 1,998, hal ini berarti t tabel 1,9839 < t hitung 1,998 kemudian hasil signifikasi sebesar 0,049 yaitu $<0,05$ maka H0 ditolak dan H1 diterima. Maka kesimpulannya ada pengaruh positif dan signifikan kualitas produk (X3) terhadap keputusan pembelian konsumen produk Moorlife (Y). Nilai Adjusted $R$ square diperleh sebesar sebesar 0,464 atau 46,4\%. Hal ini berarti bahwa 46,4\% keputusan pembelian (Y) dapat dijelaskan oleh variabel promosi (X1), garansi (X2) dan kualitas produk (X3). Sedangkan 53,6\% dipengaruhi oleh variabel-variabel lain diluar model penelitian.

\section{Daftar Pustaka}

Andrew F. Manampiring, 2016, Pengaruh Produk, Harg, Promosi, dan Tempat terhadap Keputusan Pembelian mobil di PT. Astra International Tbk. Malalayang, Jurnal EMBA, 4(1), 482.

Budi Wahyono. 2012, Pengertian Keputusan Pembelian Konsumen, Pendidikan Ekonomi, http://www.pendidikanekonomi.com/2012/10/pengertian-keputusan-pembelian-konsumen.html?m=1

Gunawan Setiaji, Pengaruh Garansi Produk dan dan Citra Merek Terhadap keputusan Pembelian Smartphone di Kota Solo, Skripsi, Universitas Muhammadiyah Yogyakarta, Yogyakarta. 2017

Jilly Bernadette M., 2003, Promosi, Distribus, Harga Pengaruhnya Terhadap Keputusan Pembelian Rokok Surya Promid, Jurnal EMBA, 1(4), 95-104.

Moorlife, 2020, System Data Omset Per Tahun https://system.ilovecmn.com/auth26 April 2020

Rahajeng Sulistyaningtyas, dkk, 2017, Pengaruh Kualitas Produk, Harga, Promosi Terhadap Keputusan Pembelian (Studi pada pelanggan Tupperware di IIK Bhakti Wiyata Kediri), Jurnal Ilmu Manajemen, 6(3), 2.

Sari Asri Fajar, 2015, Pengaruh Harga, Kualitas Produk dan Promosi Terhadap Keputusan Pembelian Lemari es merek LG di PT. Global Elektronik Banyumanik Semarang, Jurnal of management, 1(1), 3.

Yuli Ikawanti, 2017, Pengaruh Kualitas Produk dan Citra Merek Terhadap Keputusan Pembelian Produk Tupperware di Toko Sakinah Jambang Surabaya, Jurnal Pendidikan Tata Niaga, 1(1), 2.

Wikipedia, Pengertian Garansi Produk, 2020, Https://id.m.wikipedia.org/wiki/Garansi. 26 April 2020 